\title{
MODEL ALTERNATIF UNTUK MEMBANGUN SISTEM INFORMASI PERENCANAAN PAJAK DAERAH DAN RETRIBUSI DAERAH
}

\author{
Tony Seno Aji \\ Fakultas Ekonomi Universitas Negeri Surabaya \\ Jalan Ketintang Surabaya, Jawa Timur 60231 Indonesia Telepon +62-031-8285362, 031-8280009 \\ E-mail: tonysenoaji@yahoo.com
}

Diterima 20 September 2010/Disetujui 19 Oktober 2010

\begin{abstract}
This research aimed to develop and coincidentally to improve the planning model of current the regional revenue and retribution (PDRD). This research is also to accommodate PDRD, the managerial capability of government and the regional macroeconomic condition, which have been neglected. Macroeconomic variable selection that influenced PDRD for the two-wheel and four-wheel vehicles were the government expenditure and the interest rate, and for more-than-four-wheel vehicles were the government expenditure and exchange rate. The potential of parking tax which was achieved from the tax payers in the year 2009 reached by Rp733,937,632 and the total value of parking retribution potential in that same year was $R p 548,440,103$. The attainment of PDRD only around half from its potency. The trend of Financial Capability Index from 2004 to 2008 declined and belonged to medium category. As a whole, the coverage ratio of the regional revenue and retribution of Gresik Municipality was 48.58 percent, which means that the collectiveness of the regional revenue and retribution is considered to be in the condition of far below its optimum level.
\end{abstract}

Keywords: regional revenue, regional retribution, tax potential, signal approach

\begin{abstract}
Abstrak: Penelitian ini bertujuan membangun model perencanaan pajak daerah dan retribusi daerah (PDRD) guna memperbaiki model perencanaan PDRD yang telah ada. Penelitian ini juga mengakomodir potensi PDRD, kemampuan manajemen pengelola, dan mempertimbangkan kondisi makroekonomi daerah yang selama ini kurang diperhatikan. Hasil seleksi variabel makroekonomi yang mempengaruhi PDRD untuk parkir roda dua dan roda empat adalah pengeluaran pemerintah dan suku bunga, sedangkan untuk kendaraan parkir roda lebih dari empat adalah kurs dan pengeluaran pemerintah. Potensi pajak parkir pada tahun 2009 sebesar Rp733.937.632 dan potensi retribusi parkirnya sebesar Rp548,440,103. Pencapaian PDRD hanya sekitar setengah dari potensi. Indeks Kemampuan Keuangan Kabupaten Gresik sejak tahun 2004 hingga 2008 sangat fluktuatif dan termasuk kategori sedang. Secara keseluruhan, nilai coverage ratio PDRD Kabupaten Gresik adalah sebesar 48.58 persen, yang berarti kolektibilitas PDRD berada pada kondisi yang jauh di bawah tingkat optimalnya.
\end{abstract}

Kata kunci: pajak daerah, retribusi daerah, potensi pajak, signal approach

\section{PENDAHULUAN}

Desentralisasi mengemban misi utama pelimpahan wewenang dari pemerintah pusat ke pemerintah daerah dan pelimpahan beberapa wewenang pemerintah ke pihak swasta dalam bentuk privatisasi (Mardiasmo, 2004). Sejak de- sentralisasi fiskal digulirkan, penyelenggaraan anggaran di banyak kabupaten dan kota di Indonesia, diwarnai dengan adanya kecenderungan makin tingginya fiscal gap antara fiscal capacity dan fiscal need. Kontribusi pajak daerah dan retribusi daerah (PDRD) terhadap total belanja semakin kecil, sehingga tingkat keter- 
gantungan terhadap bagi hasil pajak dan non pajak dari pemerintah pusat maupun dari pemerintah provinsi, serta dana alokasi umum (DAU) semakin besar. Kondisi ini secara langsung akan menurunkan tingkat kemandirian keuangan daerah.

Perencanaan PDRD di daerah selama ini banyak yang menerapkan incremental method dan PAFPACK (program and financial planning analysis control-koordinasi). Pada incremental method, penetapan target hanya didasarkan pada rata-rata perubahan tiap tahun jenis pendapatan yang diamati kemudian ditambah atau dikurangi dengan suatu persentase tertentu yang ditetapkan hanya secara intuitif. Sedangkan PAFPACK, penetapan target didasarkan pada metode time series dengan pola linier (IIP, 2002).

Kegagalan model perencanaan PDRD yang selama ini diterapkan di daerah kabupaten/ kota tercermin dari indeks kemampuan keuangannya (IKK). Biasanya masing-masing daerah kabupaten/kota mempunyai kecenderungan secara nominal memang PDRD-nya tampak meningkat dari tahun ke tahun, namun jika dilihat IKK-nya cenderung terus menurun. Hal ini menunjukkan makin melemahnya kemampuan keuangan daerah kabupaten/kota dari tahun ke tahun (Dwiyoso, 2007). Untuk meningkatkan kemampuan keuangan daerah diperlukan model baru. Model yang ditawarkan dalam penelitian ini adalah kolaborasi signal approach dan probability approach.

Penerapan signal approach akan dihasilkan sinyal-sinyal (indikator) terhadap kemungkinan gejolak potensi pendapatan sehingga kebijakan antisipatifnya dengan cepat dapat ditentukan. Pada penelitian ini signal approach digunakan untuk menentukan leading indicators dari fluktuasi potensi PDRD yang dipengaruhi oleh fluktuasi aktivitas ekonomi daerah. Kemudian, untuk menentukan tingkat pertumbuhan potensi pendapatan PDRD, leading indicators tersebut dimasukkan sebagai predictors ke model kointegrasi yang memasukkan unsur lag di dalamnya. Dari hasil estimasi model ini diperoleh proyeksi tingkat pertumbuhan potensi pendapatan PDRD. Pendekatan seperti ini lazim disebut dengan probability approach.

Kolaborasi signal approach dan probability approach bersandar pada data dasar yang menggambarkan potensi pendapatan, kemampuan dan permasalahan internal manajemen pengelolanya, serta mengakomodir kondisi makroekonomi daerah ke dalam model. Kolaborasi dua pendekatan ini akan menghasilkan perencanaan yang tidak berpola linier, namun mengikuti fluktuasi kondisi makroekonomi daerah.

Tujuan umum dalam penelitian ini adalah memperoleh peta informasi potensi PDRD di Kabupaten Gresik. Secara spesifik tujuan penelitian adalah: (1) Mengidentifikasi Variabel makroekonomi yang bisa digunakan untuk memprediksi pajak daerah dan retribusi daerah di Kabupaten Gresik, (2) Mengetahui banyak potensi pajak daerah dan retribusi daerah (dengan pilot project pajak parkir dan retribusi parkir) di Kabupaten Gresik, (3) Menganalisis kemampuan dan permasalahan internal manajemen yang terkait dengan pajak daerah dan retribusi daerah di Kabupaten Gresik.

\section{METODE PENELITIAN}

\section{Penentuan Indikator Makroekonomi}

Ada sejumlah tahapan untuk mengetahui indikator makroekonomi daerah yang berpengaruh. Tahapan dan alat analisis yang diperlukan sebagai berikut:

(1) Menentukan Leading Indicators. Pada penelitian ini, leading indicator ditentukan untuk nantinya dipergunakan sebagai predictor bagi prediksi pertumbuhan PDRD yang diamati. Kandidat leading indicators merupakan variabelvariabel makroekonomi pengukur indikator makroekonomi yang mewakili sektor riel, sektor moneter, serta ekonomi global. Kemudian dilakukan cross-correlations antara nilai potensi masing-masing PDRD yang diamati dengan seluruh kandidat leading indicators.

(2) Menyusun Distributed Lag Model dengan Pendekatan Cointegration. Distributed lag model disusun nantinya untuk memprediksi pertumbuhan potensi PDRD yang diamati. Bentuk dasar model distributed lag pada penelitian ini mengadopsi dan memodifikasi model distributed lag yang dikembangkan oleh Schmidt dan Waud dalam Ramanathan (1994). Model dis- 
tributed lag dalam penelitian ini adalah:

$$
\begin{aligned}
\Delta Y_{t}= & \alpha+\beta_{1} \Delta X_{1 t-k}+\beta_{2} \Delta X_{2 t-k}+\beta_{3} \Delta X_{3 t-k}+ \\
& \ldots . .+\beta_{n} \Delta X_{n t-k}+e_{t}
\end{aligned}
$$

$\Delta \mathbf{Y}$ merupakan pertumbuhan potensi PDRD yang diamati, $\boldsymbol{\Delta} \mathbf{X}$ adalah pertumbuhan dari indikator-indikator makroekonomi daerah yang terpilih menjadi prediktor, $\mathbf{\alpha}$ dan $\boldsymbol{\beta}$ adalah intercept dan koefisien model, dan e adalah error term. Sedangkan nilai $\mathbf{k}$ ditentukan pada tahap menentukan leading indicators sebelum ini.

\section{Penghitungan Potensi Pajak Parkir dan Retribusi Parkir}

Formula penghitungan potensi beserta variabelvariabel perhitungannya untuk masing-masing PDRD yang diamati pada penelitian ini adalah sebagai berikut:

\section{(1) Formula Potensi Pajak Parkir}

$$
P o t=J K P * T J P * T P P * W H
$$

JKP merupakan jumlah kendaraan parkir (ratarata tingkat hunian sepi dan ramai); TJP adalah tarif jasa parkir; TPP ialah tarif pajak parkir; dan WH adalah waktu hari dalam setahun.

\section{(2) Formula Potensi Retribusi Parkir}

$$
P o t=J K P * T R P * P B O * W H
$$

JKP merupakan jumlah kendaraan parkir (ratarata tingkat hunian sepi dan ramai); TRP adalah tarif retribusi parkir; PBO adalah proporsi biaya operasional; dan WH merupakan jumlah hari dalam setahun.

\section{Penilaian Kemampuan Manajemen}

Alat analisis kuantitatif yang dipergunakan untuk menilai kemampuan manajemen pengelola PDRD adalah:

(1) Indeks Kemampuan Keuangan (IKK). IKK merupakan rata-rata hitung dari growth index $(g r)$, share index (sh), dan elasticity index (e) dari PDRD.

$$
I K K_{t}=\frac{I g r_{t}+I s h_{t}+I e_{t}}{3}
$$

\section{(2) Coverage Ratio}

$$
C R=\frac{\text { Realisasi } P D R D_{t-1}}{\text { Potensi } P D R D_{t}} * 100 \%
$$

CR dicari dengan cara membagi realisasi PDRD tahun sebelumnya dengan nilai potensi yang telah dihitung pada tahun dasar (tahun penelitian).

\section{HASIL DAN PEMBAHASAN}

\section{Seleksi Variabel Makroekonomi}

Seluruh variabel makroekonomi regional Kabupaten Gresik yang diamati kemudian diseleksi untuk ditentukan apakah suatu variabel merupakan prediktor atau variabel eksternal yang mempengaruhi perilaku masing-masing PDRD tertentu (predictand) melalui sejumlah variabelvariabel perhitungannya. Setelah dilakukan detrending dengan menggunakan HP filter terhadap seluruh kandidat prediktor dan predictand, kemudian dilakukan cross-correlations antara residual growth (fluktuasi) masing-masing predictand tersebut dengan seluruh residual growth kandidat prediktor.

Terdapat tiga variabel perhitungan pajak parkir dan retribusi parkir, yaitu jumlah kendaraan parkir roda dua, jumlah kendaraan parkir roda empat, dan jumlah kendaraan parkir roda lebih dari empat.

Masing-masing variabel perhitungan memiliki komposisi prediktor yang tidak sama. Prediktor untuk kendaraan parkir roda dua adalah pengeluaran pemerintah, dan suku bunga (lihat Tabel 1). Ternyata prediktor untuk kendaraan parkir roda empat juga sama yaitu suku bunga dan pengeluaran pemerintah (lihat Tabel 2).

Prediktor untuk kendaraan parkir roda lebih dari empat berbeda dengan parkir roda dua dan parkir roda empat, yaitu kurs dan pengeluaran pemerintah (lihat Tabel 3). Namun demikian pengeluaran pemerintah sama-sama menjadi prediktor bagi ketiganya.

\section{Perhitungan Potensi Pajak Daerah dan Retribusi Daerah}

Sebelum dilakukan proyeksi terhadap potensi 
Tabel 1. Participant Indicators dari Parkir Kendaraan Roda Dua

\begin{tabular}{clcclc}
\hline No & \multicolumn{1}{c}{ Indicators } & \multicolumn{2}{c}{ Cross-correlation } & Direction & AIC \\
& & Lag & Coefficient & & \\
\hline${ }^{*} 1$ & Pengeluaran Pemerintah & 4 & $-0,7929$ & Countercyclical & 4,0369 \\
${ }^{*} 2$ & Suku Bunga & 2 & 0,7630 & Procyclical &, 1423 \\
3 & Kurs Rp & 3 & 0,7106 & Procyclical & 4,3163 \\
4 & PDRB & 2 & 0,6178 & Procyclical & 4,5045 \\
5 & Sektor Keuangan & 2 & $-0,5543$ & Countercyclical & 4,4475 \\
6 & Inflasi & 4 & $-0,5434$ & Countercyclical & 4,5174 \\
7 & Sektor Manufaktur & 2 & 0,4532 & Procyclical & 4,5369 \\
8 & Sektor Perdagangan & 2 & 0,4495 & Procyclical & 3,6431 \\
\hline
\end{tabular}

Ket.: * Participant indicators yang terpilih sebagai predictor

Tabel 2. Participant Indicators dari Parkir Kendaraan Roda Empat

\begin{tabular}{clcccc}
\hline \multirow{2}{*}{ No } & \multicolumn{1}{c}{ Indicators } & \multicolumn{2}{c}{ Cross-correlation } & \multirow{2}{*}{ Direction } & \multirow{2}{*}{ AIC } \\
\cline { 3 - 4 } & & Lag & Coefficient & & \\
\hline$* 1$ & Suku Bunga & 2 & 0,6953 & Procyclical & 3,3408 \\
2 & PDRB & 2 & 0,6239 & Procyclical & 2,9880 \\
$* 3$ & Pengeluaran Pemerintah & 4 & $-0,5310$ & Countercyclical & 1,0725 \\
4 & Sektor Keuangan & 2 & $-0,5228$ & Countercyclical & 3,1276 \\
5 & Kurs & 3 & 0,5117 & Procyclical & 3,8063 \\
6 & Sektor Perdagagan & 2 & 0,4575 & Procyclical & 3,3691 \\
7 & Sektor Manufaktur & 2 & 0,4168 & Procyclical & 3,2730 \\
\hline
\end{tabular}

Ket.: * $=$ Participant indicators yang terpilih sebagai predictor.

Tabel 3. Participant Indicators dari Kendaraan Parkir Roda Lebih dari Empat

\begin{tabular}{clcccr}
\hline No & \multicolumn{1}{c}{ Indicators } & \multicolumn{2}{c}{ Cross-correlation } & Direction & AIC \\
\cline { 3 - 4 } & & Lag & Coefficient & & \\
\hline$* 1$ & Kurs & 3 & 0,6523 & Procyclical & 2,3134 \\
$* 2$ & Pengeluaran Pemerintah & 4 & $-0,5937$ & Countercyclical & 0,7280 \\
3 & Suku Bunga & 2 & 0,5151 & Procyclical & 2,5408 \\
4 & IHK & 2 & 0,4488 & Procyclical & 1,9658 \\
5 & Inflasi & 4 & $-0,4068$ & Countercyclical & 2,4637 \\
\hline
\end{tabular}

Ket.: * Participant indicators yang terpilih sebagai predictor.

masing-masing PDRD yang diamati, maka terlebih dahulu dilakukan perhitungan potensi masing-masing PDRD pada tahun dasar (2009) yang nantinya akan dijadikan patokan untuk melakukan proyeksi potensi selama beberapa tahun ke depan.

(1) Potensi Pajak Parkir. Dari 64 wajib pajak parkir yang terdata, diperoleh nilai potensi pajak parkir pada Tahun 2009 adalah sebesar Rp733.937.632, lihat Tabel 4.

Dari total potensi pajak parkir tersebut, 51,43 persen merupakan sumbangan dari pajak parkir kendaraan roda dua, sedangkan sisanya
(48,57 persen) merupakan sumbangan pajak parkir kendaraan roda empat.

Tabel 4. Rekapitulasi Hasil Perhitungan Potensi Pajak Parkir Tahun 2009 Menurut Kategori Jenis Kendaraan

\begin{tabular}{lrr}
\hline Pajak Parkir & Potensi 2009 (Rp) & Share \\
\hline Kendaraan Roda 2 & 377.434 .348 & $51,43 \%$ \\
Kendaraan Roda 4 & 356.503 .284 & $48,57 \%$ \\
Kendaraan Roda $>4$ & 0 & $0 \%$ \\
Total Potensi & $\mathbf{7 3 3 . 9 3 7 . 6 3 2}$ & $\mathbf{1 0 0 \%}$ \\
\hline
\end{tabular}


(2) Retribusi Parkir. Dari 19 lokasi yang disurvei, diperoleh nilai total potensi retribusi parkir Tahun 2009 adalah Rp548.440.103. Dengan hanya mendasarkan atas data survei di 19 lokasi parkir, ternyata hasil perhitungan potensinya telah jauh melebihi nilai realisasinya, yaitu sebesar Rp238.959.750 (setengah dari nilai potensinya). Perbedaan ini akan semakin lebar lagi jika survei dilakukan terhadap semua lokasi parkir potensial di Gresik (lihat Tabel 5).

Tabel 5. Rekapitulasi Hasil Perhitungan Potensi Retribusi Parkir Tahun 2009 Menurut Kategori Jenis Kendaraan

\begin{tabular}{lrr}
\hline \multicolumn{1}{c}{ Pajak Parkir } & $\begin{array}{c}\text { Potensi 2009 } \\
(\mathbf{R p})\end{array}$ & Share \\
& 323.688 .809 & $59,02 \%$ \\
\hline Kendaraan Roda 2 & 206.559 .936 & $37,66 \%$ \\
Kendaraan Roda 4 & 18.191 .358 & $3,32 \%$ \\
Kendaraan Roda $>4$ & 548.440 .103 & $100 \%$ \\
Total Potensi & \\
\hline
\end{tabular}

\section{(3) Model Kointegrasi Pertumbuhan Potensi}

PDRD. Guna memprediksi pertumbuhan potensi PDRD, diperlukan untuk menyusun suatu model probabilistik dalam bentuk distributed lag model dengan pendekatan cointegration, dan berdasarkan hasil seleksi predictor atau variabel eksternal yang mempengaruhi perilaku masing-masing PDRD yang telah dibahas sebelumnya, maka diperoleh model untuk masingmasing variabel perhitungan PDRD sebagai berikut:

(a) Model Kointegrasi Parkir Kendaraan Roda Dua.

Bentuk fungsi dasarnya adalah $\Delta R 2=f(\Delta G$, $\triangle S B) . \Delta R 2$ adalah pertumbuhan potensi kendaraan roda dua yang parkir yang di-proxy oleh pertumbuhan jumlah kendaraan roda dua di Kabupaten Gresik, $\Delta G$ merupakan pertumbuhan pengeluaran pemerintah Kabupaten Gresik, dan $\triangle S B$ merupakan pertumbuhan rata-rata suku bunga deposito dengan jangka waktu satu bulan.

Berdasarkan hasil estimasi model kointegrasi pertumbuhan potensi kendaraan roda dua parkir di Kabupaten Gresik dapat ditulis sebagai berikut:

$$
\begin{gathered}
\Delta R 2_{t}=25,4119-0,1904 \Delta G_{t-4}- \\
0,0818 \Delta S B_{t-2}+e_{t}
\end{gathered}
$$

Sebelum model tersebut dipergunakan untuk melakukan prediksi, diperlukan untuk melakukan stationarity test, yaitu dengan menerapkan uji akar unit maupun uji derajat integrasi (lihat Tabel 6).

Tabel 6. Hasil Uji Kointegrasi Variabel-variabel Pendukung Model Kointegrasi Pertumbuhan Potensi Parkir Kendaraan Roda Dua

\begin{tabular}{ccccc}
\hline Var. & ADF $_{\text {stat }}$ & $\begin{array}{c}\text { Prob. } \\
\text { ADF }\end{array}$ & $\mathbf{I}(\boldsymbol{d})$ & Keterangan \\
\hline$e$ & $-3,2277$ & 0,0139 & $\mathrm{I}(0)$ & Stasioner \\
\hline
\end{tabular}

Secara meyakinkan $(\alpha=1 \%)$ error term $(e)$ dari model kointegrasi pertumbuhan potensi kendaraan roda dua parkir di Kabupaten Gresik ternyata stasioner. Ini menunjukkan bahwa variabel-variabel penyusun model tersebut adalah berkointegrasi. Sehingga regresi dengan menggunakan data orisinal-nya akan menghasikan regresi yang bermakna. Model tersebut sekarang dapat benar-benar disebut sebagai model kointegrasi.

(b) Model Kointegrasi Parkir Kendaraan Roda Empat. Bentuk fungsi dasarnya adalah $\Delta R 4=$ $f(\Delta G, \Delta S B)$. Dimana $\Delta R \mathbf{4}$ adalah pertumbuhan potensi kendaraan roda empat yang parkir yang di-proxy oleh pertumbuhan jumlah kendaraan roda empat di Kabupaten Gresik, $\Delta G$ merupakan pertumbuhan pengeluaran pemerintah Kabupaten Gresik, dan $\Delta S B$ merupakan pertumbuhan rata-rata suku bunga deposito dengan jangka waktu satu bulan.

Hasil estimasi model kointegrasi pertumbuhan potensi kendaraan roda empat parkir di Kabupaten Gresik dapat ditulis sebagai berikut:

$$
\begin{gathered}
\Delta R 4_{t}=11,8294-0,0659 \Delta G_{t-4}- \\
0,0191 \Delta S B_{t-2}+e_{t}
\end{gathered}
$$

Seperti pada variabel perhitungan sebelumnya, untuk mempersingkat proses maka pada model tidak dilakukan stationarity test, tetapi langsung menerapkan cointegration test untuk membentuk model cointegration guna menghindari spurious cyclicality problem/ spurious regression atau regresi palsu (Tabel 7). 
Tabel 7. Hasil Uji Kointegrasi Variabel-variabel Pendukung Model Kointegrasi Pertumbuhan Potensi Parkir Kendaraan Roda Empat

\begin{tabular}{ccccc}
\hline Var. & ADF $_{\text {stat }}$ & $\begin{array}{c}\text { Prob. } \\
\text { ADF }\end{array}$ & $\mathbf{I}(d)$ & Keterangan \\
\hline$e$ & $-3,2277$ & 0,0139 & $\mathrm{I}(0)$ & Stasioner \\
\hline
\end{tabular}

Secara meyakinkan $(\alpha=1 \%)$ error term (e) dari model kointegrasi pertumbuhan potensi kendaraan roda empat parkir di Kabupaten Gresik ternyata stasioner. Ini menunjukkan bahwa variabel-variabel penyusun model tersebut adalah berkointegrasi. Sehingga regresi dengan menggunakan data orisinalnya akan menghasikan regresi yang bermakna. Model tersebut sekarang dapat benar-benar disebut sebagai model kointegrasi.

(c) Model Kointegrasi Parkir Kendaraan Roda Lebih dari Empat. Bentuk fungsi dasarnya adalah $\Delta R l d 4=f(\Delta G, \Delta K)$. Dimana $\Delta R l d 4$ adalah pertumbuhan potensi kendaraan roda lebih dari empat yang parkir yang di proxy oleh pertumbuhan jumlah kendaraan roda lebih dari empat di Kabupaten Gresik, $\Delta G$ merupakan pertumbuhan pengeluaran pemerintah Kabupaten Gresik, dan $\Delta K$ merupakan pertumbuhan kurs Rupiah terhadap US Dollar.

Berdasarkan hasil estimasi model kointegrasi pertumbuhan potensi kendaraan roda lebih dari empat parkir di Kabupaten Gresik dapat ditulis sebagai berikut:

$$
\begin{gathered}
\Delta \text { Rld }_{t}=9,3028-0,0356 \Delta G_{t-4}- \\
0,0423 \Delta K_{t-3}+e_{t}
\end{gathered}
$$

Tabel 8. Hasil Uji Kointegrasi Variabel-variabel Pendukung Model Kointegrasi Pertumbuhan Potensi Parkir Kendaraan Beroda Lebih dari Empat

\begin{tabular}{ccccc}
\hline Var. & $\mathbf{A D F}_{\text {stat }}$ & $\begin{array}{c}\text { Prob. } \\
\text { ADF }\end{array}$ & $\mathbf{I}(d)$ & Keterangan \\
\hline$e$ & $-1,7959$ & 0,0744 & $\mathrm{I}(0)$ & Stasioner \\
\hline
\end{tabular}

Secara cukup meyakinkan ( $\alpha=10 \%)$ error term (e) dari model kointegrasi pertumbuhan potensi kendaraan roda lebih dari empat parkir di Kabupaten Gresik ternyata stasioner. Ini menunjukkan bahwa variabel-variabel penyusun model tersebut adalah berkointegrasi.

Untuk memproyeksikan potensi masingmasing PDRD yang diamati, maka pertumbuhan dari variabel-variabel perhitungannya harus diproyeksikan atau diprediksi terlebih dahulu. Prediksi terhadap variabel-variabel perhitungan potensi masing-masing PDRD menggunakan ketiga model distributed lag model dengan pendekatan cointegration yang telah berhasil disusun sebelumnya. Dari ketiga model untuk memprediksi variabel-variabel perhitungan masing-masing PDRD, diperoleh hasil prediksi Tahun 2010 sampai 2012 beserta kriteria performance dari masing-masing network tersebut.

Dalam Tabel 9 tampaknya semua kriteria performance untuk ketiga model prediksi variabel-variabel perhitungan masing-masing PDRD, menunjukkan hasil yang baik karena nilai MSEnya adalah minimal sehingga RMSE juga mi-

Tabel 9. Hasil Prediksi Pertumbuhan Variabel Perhitungan Potensi PDRD Kabupaten Gresik dan Performance Metodologinya

\begin{tabular}{crrr}
\hline Tahun & \multicolumn{3}{c}{ Growth } \\
\cline { 2 - 4 } & Roda 2 & Roda 4 & Roda $>\mathbf{4}$ \\
\hline 2002 & 14,7970 & 4,7200 & 4,7120 \\
2003 & 13,3410 & 9,2600 & 8,6680 \\
2004 & 13,7360 & 6,3710 & 9,0180 \\
2005 & $14,79,70$ & 7,6300 & 9,1460 \\
2006 & 5,5510 & 4,7190 & 4,7180 \\
2007 & 16,7930 & 8,8940 & 7,2070 \\
2008 & 17,3370 & 9,2210 & 8,5620 \\
2009 & 18,4620 & 9,9660 & 9,3430 \\
2010 & 24,9423 & 11,6330 & 8,8104 \\
2011 & 18,5303 & 9,4287 & 8,0355 \\
2012 & & & 8,8216 \\
& & & \\
RSS & 1,2102 & 0,1527 & 0,1082 \\
MSE & 0,0098 & 0,0012 & 0,0009 \\
RMSE & 0,0988 & 0,0351 & 0,0295 \\
ESS & 114,7244 & 70,5198 & 35,9533 \\
TSS & 115,9347 & 70,6725 & 36,0615 \\
R2 & 0,9896 & 0,9978 & 0,9970 \\
R & 0,9948 & 0,9989 & 0,9985 \\
\hline
\end{tabular}


nimal, dan karena itu pula nilai $R$ dan $R^{2}$-nya adalah maksimal. Dari tingginya nilai $R^{2}$ untuk ketiga variabel perhitungan tersebut, yang berkisar antara 98,96 persen sampai 99,78 persen, menunjukkan begitu mendekatinya nilai predicted keenam variabel perhitungan tersebut dengan nilai aktualnya. Rendahnya nilai MSE, dan RMSE untuk setiap variabel perhitungan masing-masing PDRD, juga menunjukkan bahwa keenam model tersebut mempunyai kemampuan prediksi yang baik, karena rendahnya nilai MSE yang berkisar antara 0,0009 hingga 0,098, menunjukkan rendahnya tingkat kesalahan prediksi dari metode prediksi yang dipergunakan.

\section{Kemampuan Internal Manajemen}

Sebelum menghitung Indeks Kemampuan Keuangan (IKK) maka perlu untuk menghitung komponen-komponennya, yaitu pertumbuhan PDRD, share PDRD terhadap belanja rutin dan pembangunan, elasticity PDRD terhadap perubahan kondisi perekonomian regional. Dari ketiga unsur tersebut dapat ditentukan nilai Indeks Kemampuan Keuangan (IKK). IKK Kabupaten Gresik tampak cenderung menurun dari tahun ke tahun, dapat dilihat pada Gambar 1.

Metode yang dipergunakan untuk menilai prestasi PDRD adalah yang dikenal sebagai rasio prestasi atau coverage ratio $(\mathrm{CR})$, yang diperoleh dengan membagi tingkat target atau realisasi PDRD dengan nilai potensi yang telah dihitung pada tahun dasar itu pula.

Proses penghitungannya diawali dengan menghitung perbandingan antara target APBD tahun anggaran berjalan (apabila kegiatan dilakukan pada awal tahun atau lebih) atau realisasi tahun lalu (apabila kegiatan dilakukan pada awal tahun anggaran) dengan hasil perhitungan potensi pada tahun anggaran berjalan.

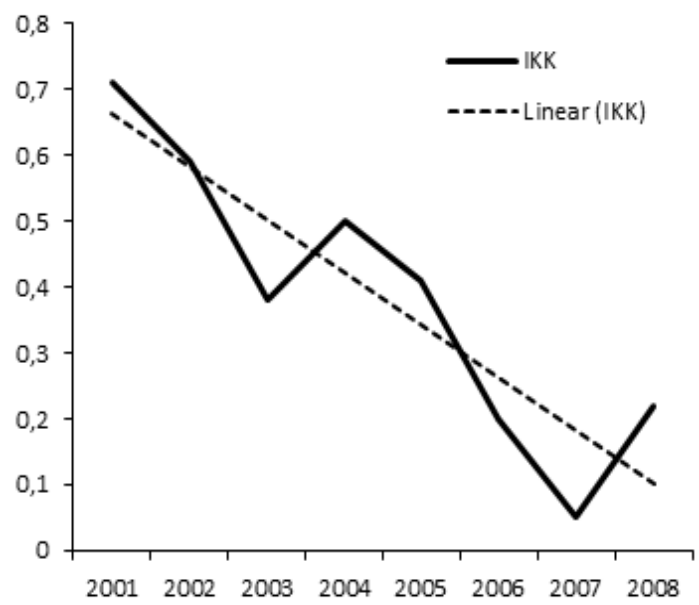

Gambar 1. IKK Kabupaten Gresik Tahun 2001-2008

Dari hasil perbandingan tersebut diperoleh nilai rasio cakupan atau coverage ratio (CR), Lihat Tabel 10.

Hasil perhitungan $\mathrm{CR}$ retribusi parkir diperoleh sebesar 75,63 persen. Jika dibandingkan dengan pajak parkir, nilai $C R$ retribusi parkir tersebut menunjukkan bahwa kolektibilitas retribusi parkir jauh lebih baik walaupun berada pada kondisi yang masih di bawah tingkat optimalnya.

\section{HASIL DAN PEMBAHASAN}

\section{Variabel Makroekonomi yang Mempenga- ruhi PDRD}

Ada temuan yang cukup menarik pada tahap seleksi predictor ini, yaitu hampir pada semua variabel perhitungan, pengeluaran pemerintah selalu masuk dalam kelompok timing yang coincident, yang berarti bahwa tingkat pengeluaran pemerintah selalu memiliki pergerakan

Tabel 10. Deviasi Realisasi dan Potensi, serta CR PDRD Tahun 2009

\begin{tabular}{|c|c|c|c|c|c|c|}
\hline \multirow{2}{*}{ No PAD } & \multirow{2}{*}{$\begin{array}{c}\text { Realisasi } 2008 \\
(\mathbf{R p})^{*}\end{array}$} & \multirow{2}{*}{$\begin{array}{l}\text { Potensi } 2009 \\
(\mathbf{R} p)^{* *}\end{array}$} & \multicolumn{2}{|c|}{ Deviasi ${ }^{* *}$} & \multirow{2}{*}{ CR $\%)^{* *}$} & \multirow{2}{*}{$\Delta \mathrm{CR} \%{ }^{*}$} \\
\hline & & & $\mathrm{Rp}$ & $\%$ & & \\
\hline 1. Pajak parkir & 208.160 .000 & 733.937 .632 & 525.777 .632 & 252,58 & 28,36 & 71,64 \\
\hline 2. Retribusi parkir & 414.799 .500 & 548.440 .103 & 133.640 .602 & 32,22 & 75,63 & 24,37 \\
\hline Jumlah & 622.959 .500 & 1.282 .377 .735 & 659.418 .235 & 105,85 & 48,58 & 51,42 \\
\hline
\end{tabular}

Sumber: $)^{*}$ Dispenda Gresik 
dalam waktu yang tepat sama dengan masingmasing PDRD. Tingkat pengeluaran pemerintah juga selalu memiliki arah koefisien korelasi yang negatif. Dengan kata lain, tingkat pengeluaran pemerintah memiliki direction yang countercyclical terhadap pergerakan masing-masing PDRD, atau pergerakan tingkat pengeluaran pemerintah selalu berlawanan arah dengan pergerakan masing-masing PDRD. Makin tinggi pengeluaran pemerintah, maka makin rendah pertumbuhan dari masing-masing PDRD, dan hubungan ini masuk dalam kategori hubungan yang kuat karena nilai koefisien korelasinya berkisar antara $-0,53$ sampai $-0,79$. Karena itu, penting bagi otoritas perencana pembangunan Kabupaten Gresik untuk mencermati pengeluaran pemerintah regional, serta menerapkan kebijakan-kebijakan yang mengarah pada kontrol pengeluaran pemerintah, demi pencapaian pertumbuhan PDRD.

Selain pengeluaran pemerintah, suku bunga juga menjadi prediktor untuk parkir roda dua dan roda empat. Hal ini terkait dengan hasrat masyarakat untuk mengajukan kredit motor dan mobil. Semakin murah beban bunga akan meningkatkan pengajuan kredit motor dan mobil yang selanjutnya akan berdampak pada semakin banyaknya jumlah kendaraan yang parkir.

Kendaraan beroda lebih dari empat prediktornya pengeluaran pemerintah dan kurs. Terpilihnya kurs menjadi prediktor bukan hal yang aneh karena Kabupaten Gresik merupakan daerah industri yang outputnya tidak hanya melayani pasar pasar domestik tetapi juga luar negeri. Sehingga aktivitas angkutan kendaraan-kendaran besar sangat dipengaruhi kurs yang pada akhirnya bisa mempengaruhi PDRD dari parkir.

\section{Pembahasan Potensi Pajak Daerah dan Re- tribusi Daerah}

Potensi PDRD adalah suatu nilai tertentu yang menggambarkan kemampuan kontribusi PDRD yang dapat diharapkan dan menjadi tolok ukur penetapan perencanaan penerimaannya dalam kurun waktu tertentu. Arti penting diketahuinya nilai potensi adalah untuk mengukur peluang suatu daerah dalam mendapatkan pendapatan pajak dan retribusi daerah, mengingat dasar perhitungan yang dianut adalah bertumpu pada kondisi aktual transaksi yang terjadi di lapangan.

Jika dibandingkan nilai realisasi pajak parkir di tahun 2009 (Rp200.895.600) dengan nilai potensinya (Rp733.937.632) hanya sebesar sepertiganya, maka hasil perhitungan potensi pajak parkir di atas tampak sangat fantastis. Bahkan sebenarnya, hasil perhitungan potensi pajak parkir tersebut masih memungkinkan menjadi lebih besar lagi karena masih banyak wajib pajak yang belum terdata, terutama yang kecil-kecil.

Dari total potensi retribusi parkir 59,02 persen merupakan sumbangan dari retribusi parkir kendaraan roda dua, sedangkan 37,66 persen merupakan sumbangan retribusi parkir kendaraan roda empat, dan 3,32 persen merupakan sumbangan retribusi parkir kendaraan yang beroda lebih dari empat. Peluang untuk meningkatkan potensi retribusi parkir masih terbuka lebar karena lokasi parkir yang disurvei masih sangat terbatas (hanya 19 lokasi), masih banyak lokasi parkir potensial yang belum disurvei.

Jumlah Pendapatan Asli Daerah (PAD) Kabupaten Gresik dari tahun ke tahun memang tampaknya terus mengalami peningkatan. Namun bila dicermati, kenaikan yang terjadi tersebut sebenarnya memiliki kecenderungan yang semakin menurun dari tahun ke tahun. Hal tersebut tercermin dari nilai pertumbuhan PAD yang cenderung semakin menurun.

Pertumbuhan PAD Kabupaten Gresik tahun 2008 sebesar 21,23 persen sebenarnya tergolong sangat tinggi jika dibandingkan ratarata nasional pertumbuhan PAD yang sebesar 2,66 persen (berdasarkan penelitian Bappenas, Direktorat Pengembangan Otonomi Daerah, pada 30 provinsi di Indonesia). Namun terhitung sejak tahun 2001 hingga 2008 pertumbuhan PAD Kabupaten Gresik menunjukkan trend yang menurun (walaupun tahun 2008 mengalami kenaikan). Prestasi yang sudah dicapai sebelumnya menjadi tidak bermakna ketika pada tahun-tahun selanjutnya pertumbuhan PAD Kabupaten Gresik justru memiliki kecenderungan yang semakin menurun. Trend pertumbuhan PAD yang semakin menurun ini seharusnya menjadi "lampu kuning" bagi 
Pemerintah Daerah Kabupaten Gresik untuk segera mengambil langkah antisipatif di masamasa selanjutnya terhadap fenomena tersebut.

Share PAD terhadap belanja rutin dan belanja pembangunan Kabupaten Gresik tampak terus mengalami penurunan hingga tahun 2007, namun pada tahun 2008 mulai mengalami peningkatan kembali. Share PAD di tahun 2004 adalah 20,24 persen, tahun 2005 sebesar 19,28, tahun 2006 sebesar 16,27 persen, tahun 2007 sebesar 14,93 persen dan di tahun 2008 sebesar 15,82 persen. Berarti dalam lima tahun terakhir mengalami penurunan, kecuali pada tahun 2008 yang mengalami peningkatan. Kondisi ini menunjukkan ketidakstabilan kemampuan Kabupaten Gresik dalam membiayai kegiatan rutin dan kegiatan pembangunannya dan mengindikasikan lemahnya perencanaan keuangan daerah Pemerintah Kabupaten Gresik. Kondisi tersebut diperparah lagi oleh kenyataan bahwa selama tahun 2004 hingga 2008, share PAD Kabupaten Gresik selalu berada di bawah rata-rata nasional share PAD yang sebesar 27,17 persen. Berarti selama lima tahun terakhir, kemampuan Kabupaten Gresik dalam membiayai kegiatan rutin dan kegiatan pembangunannya tergolong masih relatif rendah.

Rata-rata nilai elastisitas PAD Kabupaten Gresik terhadap perubahan kondisi perekonomian regional, selama lima tahun terakhir adalah sebesar 2,71. Artinya, apabila PDRB tumbuh sebesar 1 persen maka akan diikuti pertumbuhan PAD sebesar 2,71 persen. Dengan demikian, PAD bisa dikatakan sensitif atau elastis terhadap perubahan kondisi perekonomian regional Kabupaten Gresik.

Dengan elastisnya PAD, upaya peningkatan PAD bisa dicapai dengan cara mendorong pertumbuhan perekonomian regional Kabupaten Gresik. Sayangnya sama seperti dua ukuran sebelumnya, sensitivitas PAD tersebut juga cenderung mengalami penurunan dari tahun ke tahun, bahkan di tahun 2007 hanya sebesar 1,03 . Dengan kata lain, dari tahun ke tahun upaya mendorong pertumbuhan perekonomian regional Kabupaten Gresik dalam rangka mencapai peningkatan PAD akan menjadi semakin berat.

Perilaku PAD Kabupaten Gresik sebenarnya memiliki pola perilaku yang hampir sama dengan kondisi perekonomian regionalnya. PAD Kabupaten Gresik memiliki trend pergerakan yang sama dengan kondisi perekonomian regional Kabupaten Gresik yang di-proxy oleh PDRB-nya. Keduanya memiliki trend dengan arah pergerakan yang sama, yaitu samasama positifnya. Ini memberikan indikasi bahwa keduanya memiliki hubungan dengan arah yang positif.

Untuk membuktikan secara statistik atas dugaan bahwa di antara keduanya terdapat suatu hubungan, maka dilakukan penghitungan correlations coefficient $(r)$, coefficient of determination $\left(r^{2}\right)$, antara kondisi perekonomian regional yang di-proxy oleh PDRB terhadap PAD, serta menghitung $t$ statistik. Langkah ini juga diperlukan karena nantinya sejumlah pos PDRD tertentu yang merupakan bagian dari PAD tersebut akan diproyeksikan atas dasar kondisi perekonomian regional di masa depan, maka seharusnya kondisi perekonomian regional memiliki hubungan atau berpengaruh terhadap PAD ataupun PDRD-nya.

Nilai $r$ sebesar 0,9614 menunjukkan bahwa PAD Kabupaten Gresik memang berhubungan dengan PDRB-nya. Hubungan tersebut termasuk dalam kategori hubungan yang sangat kuat karena $r$ mendekati satu, dengan arah yang positif atau searah. Hubungan ini bukan merupakan suatu hal yang bersifat kebetulan (karena perilaku data yang kebetulan sama), melainkan terjadi secara signifikan atau nyata (benar-benar ada hubungan) yang ditunjukkan oleh signifikannya nilai statistic $t$ pada tingkat a (level of significant) satu persen sekalipun ( $\alpha>$ probability of statistic $t$, atau 0.01>0.0001). Dengan demikian tidak dapat dibantah lagi serta terbukti secara statistik bahwa kondisi perekonomian regional Kabupaten Gresik memiliki hubungan yang sangat kuat dengan PAD-nya. Karena bagian terbesar komposisi PAD Kabupaten Gresik (82 persen pada tahun 2008) adalah PDRD. Dapat dikatakan pula bahwa kondisi perekonomian regional Kabupaten Gresik juga berhubungan sangat kuat dengan PDRD-nya.

Nilai $r^{2}$ sebesar 0,9242 menunjukkan bahwa sumbangan atau kontribusi pengaruh perubahan kondisi perekonomian regional Kabupaten Gresik terhadap perubahan PAD-nya adalah sebesar 92,42 persen. Dengan kata lain, 
92,42 persen perubahan PAD Kabupaten Gresik adalah sebagai akibat dari perubahan kondisi perekonomian regional atau PDRB Kabupaten Gresik, 7,58 persen sisanya adalah disebabkan oleh faktor-faktor selain PDRB. Dengan demikian, sudah sepatutnya bila proyeksi potensi PAD atau PDRD Kabupaten Gresik dilakukan dengan mempertimbangkan atau atas dasar perilaku ke depan ekonomi regional Kabupaten Gresik sendiri.

Kuatnya hubungan antara kondisi perekonomian regional Kabupaten Gresik dengan PAD, serta besarnya sumbangan atau kontribusi pengaruh perubahan kondisi perekonomian regional Kabupaten Gresik terhadap perubahan PAD, seharusnya dapat dimanfaatkan oleh otoritas perencanaan pembangunan di Kabupaten Gresik sebagai salah satu cara meningkatkan perolehan PAD ataupun PDRD. Seharusnya, melalui kebijakan-kebijakan yang mendorong pertumbuhan PDRB, maka pertumbuhan perolehan PAD juga akan dapat diraih.

Pertumbuhan PDRB yang terjadi dalam kurun waktu lima tahun terakhir (2004-2008) tidak selaras dengan pertumbuhan PAD dalam durasi waktu yang sama. Pertumbuhan PDRB tidak mampu memberikan dampak yang sama kepada pertumbuhan PAD. Tidak seperti PDRB yang memiliki trend pertumbuhan yang positif, trend pertumbuhan PAD justru semakin melemah dari waktu ke waktu. Secara absolut, PAD memang terus meningkat dari waktu ke waktu, tetapi peningkatan tersebut semakin berkurang dari waktu ke waktu pula. Jika antisipasi terhadap fenomena ini tidak segera dilakukan, maka di masa yang akan datang, PAD akan sampai pada suatu titik di mana pertumbuhannya menjadi negatif, atau secara absolut PAD akan menjadi turun nilainya.

Pertumbuhan PDRB yang tidak mampu memberikan kontribusi kepada pertumbuhan PAD, sering dihipotesiskan dengan larinya nilai tambah hasil kegiatan perekonomian suatu daerah ke luar daerah tersebut. Di Kabupaten Gresik, hal tersebut tidak terbukti secara statistik karena nilai elastisitas PAD-nya masih lebih dari satu, yang berarti bahwa nilai tambah PDRB tidak lari keluar dari Kabupaten Gresik (nilai tambah PDRB diduga lebih banyak keluar dari daerah tempat kegiatan perekonomian tersebut jika nilai elastisitasnya kurang dari satu). Kondisi ini memperkuat dugaan bahwasanya makin melemahnya kemampuan keuangan Kabupaten Gresik diakibatkan oleh faktor internal manajemen keuangan daerah Pemerintah Kabupaten Gresik sendiri, misalnya seperti lemahnya sistem perencanaan keuangan daerah yang dimiliki. Oleh karena itu, strategi-strategi untuk mengatasi masalah tersebut harus dikaitkan dengan perbaikan kualitas perencanaannya.

Potensi yang dimiliki Kabupaten Gresik untuk mengatasi masalah tersebut adalah sangat besar karena adanya kenyataan bahwa hubungan antara kondisi perekonomian regional Kabupaten Gresik dengan PAD begitu kuat, serta kontribusi pengaruh perubahan kondisi perekonomian regional Kabupaten Gresik terhadap perubahan PAD juga begitu besar.

\section{Kemampuan Internal Manajemen}

IKK Kabupaten Gresik tampak cenderung menurun dari tahun ke tahun. Hal ini juga menunjukkan kemampuan keuangan Kabupaten Gresik yang terus melemah dari tahun ke tahun. Walaupun di tahun 2004 kemampuan keuangan Kabupaten Gresik sempat dikategorikan tinggi karena IKK mencapai 0,51, namun di tahun-tahun selanjutnya terus menurun hingga mencapai IKK sebesar 0,05 di tahun 2007, dan kembali naik menjadi 0,22 di tahun 2008, dengan demikian hanya berada pada kategori sedang.

Melemahnya kemampuan keuangan Kabupaten Gresik pada semua ukuran yang diterapkan, harus diwaspadai sepenuhnya oleh Pemerintah Kabupaten Gresik. Jika dilihat dari nilai elastisitas PAD yang masih lebih dari satu, yang berarti bahwa nilai tambah PDRB tidak lari keluar dari Kabupaten Gresik (elastisitas kurang dari satu, patut diduga nilai tambah PDRB-nya lebih banyak keluar dari daerah tempat kegiatan perekonomian tersebut diselenggarakan). Dengan kondisi tersebut, maka melemahnya kemampuan keuangan Kabupaten Gresik bisa disimpulkan akibat faktor internal manajemen keuangan daerah Pemerintah Kabupaten Gresik sendiri, misalnya seperti lemahnya sistem perencanaan keuangan daerah yang ada saat ini. Karena itu, strategi-strategi untuk 
mengatasi melemahnya kemampuan keuangan tersebut harus dikaitkan dengan perbaikan kualitas perencanaannya.

Fokus pembahasan dalam analisa rasio prestasi adalah bila kondisi $C R<1$, yang menunjukkan adanya revenue gap atau kesenjangan pendapatan, dimana pos pendapatan yang bersangkutan sedang tengah mengalami permasalahan dalam pencapaian prestasinya. Angka kesenjangan ini akan bervariasi bergantung kepada berat ringan permasalahan yang dialami oleh setiap jenis PDRD. Tingkat rasio pencapaian prestasi antara realisasi atau target PDRD pada tahun dasar (tahun penelitian) dengan hasil perhitungan potensi maksimal dinyatakan dalam suatu satuan persen.

Coverage Ratio (CR) dari pajak parkir adalah sebesar 28,36 persen, yang juga berarti bahwa kolektibilitas pajak parkir pada kondisi jauh di bawah tingkat optimalnya. Nilai ini juga menunjukkan bahwa revenue gap atau kesenjangan pendapatan yang terjadi pada pajak parkir adalah sangat lebar, yaitu 100 persen28,36 persen $=71,64$ persen $(\Delta C R)$. Nilai $\Delta C R$ ini juga menunjukkan bahwa pada pajak parkir terdapat sangat banyak permasalahan (dalam pencapaiannya) yang belum terpecahkan, atau permasalahan yang dihadapi pajak parkir berada dalam kategori yang sangat berat.

Revenue gap yang terjadi pada retribusi parkir tidak selebar pajak parkir, yaitu 100 persen75,63 persen $=24,37$ persen $(\Delta C R)$. Nilai $\Delta C R$ ini juga menunjukkan bahwa pada retribusi parkir juga masih terdapat sejumlah permasalahan (dalam pencapaiannya) yang belum terpecahkan, namun permasalahan yang dihadapi retribusi parkir tidak berada dalam kategori seberat yang dihadapi pajak parkir.

Kesimpulan hasil perhitungan prestasi masing-masing PDRD menggunakan coverage ratio ternyata tidak jauh berbeda dari hasil perhitungan deviasi antara realisasi dan potensi Tahun 2009. Masalah terberat terdapat pada pajak parkir ( $\triangle \mathrm{CR} 71,64$ persen, deviasi 252,58 persen) terutama pajak parkir untuk kendaraan roda empat. Urutan berikutnya adalah retribusi parkir dengan $\triangle C R$ sebesar 24,37 persen, dan deviasi sebesar 32,22 persen.

Secara keseluruhan, nilai CR PDRD Kabupaten Gresik adalah sebesar 48.58 persen, yang berarti bahwa kolektibilitas PDRD berada pada kondisi yang jauh di bawah tingkat optimalnya. Revenue gap atau kesenjangan pendapatan yang terjadi pada PDRD Kabupaten Gresik adalah sangat lebar (lebih dari 50 persen), yaitu 100 persen- 48,58 persen $=51,42$ persen $(\Delta C R)$. Nilai ini menunjukkan bahwa secara umum, pada PDRD Kabupaten Gresik masih terdapat banyak permasalahan yang belum terpecahkan.

\section{SIMPULAN}

Variabel makroekonomi yang bisa digunakan untuk memprediksi PDRD kendaraan roda dua dan roda empat adalah pengeluaran pemerintah, dan suku bunga. Sedangkan prediktor untuk kendaraan beroda lebih dari empat adalah kurs dan pengeluaran pemerintah. Perubahan variabel-variabel tersebut bisa dijadikan signal untuk memprediksi PDRD periode selanjutnya.

Potensi pajak parkir pada tahun 2009 adalah sebesar Rp733.937.632 dan potensi retribusi parkir tahun 2009 adalah Rp548.440.103. Sementara realisasi hanya setengah dari nilai potensinya padahal belum semua lokasi parkir disurvei.

Indeks Kemampuan Keuangan dari tahun 2004 sampai 2008 trennya menurun dan masuk kategori sedang. Coverage Ratio PDRD Kabupaten Gresik sebesar 48,58 persen, yang berarti bahwa kolektibilitas PDRD berada pada kondisi yang jauh di bawah tingkat optimalnya.

Implikasi Kebijakan. Coverage ratio masih di bawah 50 persen, nilai tersebut menunjukkan bahwa secara umum PDRD Kabupaten Gresik masih terdapat banyak permasalahan yang belum terpecahkan. Oleh karena itu faktor internal manajemen keuangan daerah Pemerintah Kabupaten Gresik sendiri perlu diperbaiki. Misalnya dengan memperkuat sistem perencanaan keuangan daerah yang ada saat ini sehingga potensi yang ada bisa tergali secara optimal.

Otoritas perencana pembangunan Kabupaten Gresik perlu mencermati pengeluaran pemerintah regional, serta menerapkan kebijakankebijakan yang mengarah pada kontrol pengeluaran pemerintah, demi pencapaian pertumbuhan PDRD. Sebab tingkat pengeluaran peme- 
rintah memiliki direction yang countercyclical terhadap pergerakan masing-masing PDRD.

Keterbatasan Riset. Penelitian ini hanya menggunakan pajak parkir dan retribusi parkir untuk memperkirakan potensi pajak daerah dan retribusi daerah, agar lebih optimal dalam memperkirakan potensi pajak daerah dan retribusi daerah akan lebih baik kalau ditambah dengan retribusi pasar dan pajak penerangan jalan.

\section{DAFTAR PUSTAKA}

Adi, Priyo Hari. 2006. Hubungan Antara Pertumbuhan Ekonomi Daerah, Belanja Pembangunan dan Pendapatan Asli Daerah Studi pada Kabupaten dan Kota se JawaBali), Simposium Nasional Akuntansi 9 Padang, 23-26 Agustus 2006.

Aji, Tony Seno, dan Dianwicaksih. 2009. Model Signal Approach dan Probability Approach sebagai Model Alternatif Membangun Sistem Informasi Perencanaan Pajak Daerah dan Retribusi Daerah, Penelitian tidak dipublikasikan.

Dwiyoso, Hertoto. 2007. Perencanaan Peningkatan Pajak Daerah dan Retribusi Daerah Tahun 2007-2011. Gresik: Balitbangda Kabupaten Gresik.

Elmi, Bachrul. 2002. Studi Peningkatan Ekonomi dan Keuangan Kabupaten Lampung Utara Tahun 2002, Kajian Ekonomi dan Keuangan, 81 Vol. 7, No. 1, Maret 2003.

Institut Ilmu Pemerintahan. 2002. Perencanaan Peningkatan Pajak Daerah dan Retribusi
Daerah: Analisa Potensi dan Proyeksi. Jakarta Institut Ilmu Pemerintahan.

Mardiasmo. 2002. Otonomi dan Manajemen Keuangan Daerah. Yogyakarta: Andi Offset.

Mishkin, Frederic. 2008. The Economics of Money, Banking, and Financial Markets. New Jersey: Addison-Wesley.

Muluk, Khairul. 2006. Menggagas Peran baru Pemerintah Daerah, Jurnal Desentralisasi, Vol 7 No 4 tahun 2006.

Mulyana. 2007. Keuangan Daerah; Perspektif Desentralisasi Fiskal dan Pengelolaan APBD di Indonesia. Jakarta: BPPK-DEPKEU.

Ramanathan, Ramu. 2002. Introductory Econometrics with Applications. Fifth Edition. New York: Dryden Press.

Riduansyah, Muhammad. 2003. Kontribusi Pajak Daerah dan Retribusi Daerah terhadap Pendapatan Asli Daerah (PAD) dan Anggaran Pendapatan dan Belanja Daerah (APBD) Guna Mendukung Pelaksanaan Otonomi Daerah (Studi Kasus Pemerintah Daerah Kota Bogor), Makara, Vol 7, No 2, Desember 2003.

Susilo. 2000. Sebuah Resep dalam Upaya Peningkatan Pendapatan Asli Daerah (PAD) dengan Pendekatan Metode ZOPP, Lintasan Ekonomi, Volume XVII, Nomor 1, Januari 2000

Sutomo, Slamet, dkk. 2004. Development of Composite Leading Indicators (CLIs) in Indonesia. http://www.oecd.org/dataoecd/54/59/3 4898123.pdf. Diakses tanggal 5 Januari 2009. 